\title{
Links between serotonin reuptake inhibition during pregnancy and neurodevelopmental delay/spectrum disorders: A systematic review of epidemiological and physiological evidence
}

\author{
D. Healy ${ }^{\mathrm{a}, *}$, J. Le Noury ${ }^{\mathrm{a}}$ and D. Mangin ${ }^{\mathrm{b}}$ \\ ${ }^{a}$ North Wales Department of Psychological Medicine, Bangor University, Wales, UK \\ ${ }^{\mathrm{b}}$ David Braley Nancy Gordon Chair in Family Medicine, Department of Family Medicine, \\ McMaster University, Hamilton, ON, Canada
}

Received 25 May 2016

Accepted 12 July 2016

\begin{abstract}
.
OBJECTIVE: To investigate possible linkages between neurodevelopmental delay and neurodevelopmental spectrum disorders and exposure to medication with effects on serotonin reuptake inhibition during pregnancy.

METHODS: We systematically reviewed the epidemiological literature for studies bearing on this relationship in children born with neurodevelopmental spectrum disorder and related conditions, as well as animal studies giving serotonin reuptake inhibitors to pregnant animals and in addition reviewed the literature for proposals as to possible mechanisms that might link effects on serotonin reuptake with cognitive changes post-partum.

The epidemiological studies were analysed to produce Forest plots to illustrate possible relations.

RESULTS: The odds ratio of Autistic Spectrum or related Disorders in children born to women taking serotonin reuptake inhibiting antidepressants during pregnancy in case control studies was 1.95 (95\% C.I. 1.63, 2.34) and in prospective cohort studies was 1.96 (95\% C.I. 1.33, 2.90).

CONCLUSIONS: There appears to be a link between serotonin reuptake inhibition in pregnancy and developmental delay and spectrum disorders in infancy leading to cognitive difficulties in childhood. More work needs to be done to establish more precisely the nature of the difficulties and possible mechanisms through which this link might be mediated.
\end{abstract}

Keywords: Autism spectrum disorder, neurodevelopmental delay, neurodevelopmental spectrum disorders, antidepressants, serotonin reuptake inhibitors, pregnancy

\section{Background}

The clinical syndrome later called autism was first reported in 1943 [1]. The first studies of the prevalence of autism or autistic disorder (AD) in the 1960s pointed to a rate of 4 per 10,000 $[2,3]$. Later studies indicated the existence of a spectrum of disorders, and brought the term autistic spectrum disorder (ASD) into being in the mid-1990s [4]. The diagnosis of ASD has probably widened since then,

\footnotetext{
*Address for correspondence: D. Healy, North Wales Department of Psychological Medicine, Bangor University, Wales, UK. Tel.: +44 01248 384452; Fax: +44 01248 371397; E-mail: david.healy54@googlemail.com. 
and ASD also now includes other syndromes such as Pervasive Developmental Disorder and Aspergers Disorder so that it is difficult to know how closely current clinical usage of an ASD diagnosis maps onto AD and ASD as first conceived. Current estimates are that ASD in research studies occurs at a rate of more than 1 in 70 children $[5,6]$.

Kanner autism was recognized before the emergence of modern psychotropic drugs, and given its submergence in ASD, it may not now be possible to establish whether it is linked to commonly used psychotropic medications. A number of clinical pictures linked to psychotropic drug use, fetal anticonvulsant syndrome (FACS), fetal valproate syndrome (FVS), and fetal alcohol syndrome (FAS) and fetal alcohol spectrum disorder (FASD) have been described since 1970. Aside from the link to treatment, the clinical features of these disorders are consistent with a diagnosis of ASD but not Kanner autism. A growing number of epidemiological studies point to an increase in rates of ASD. This translates popularly into concerns about a change in the prevalence of "autism". The increase seems almost certain to be driven in part by changes in diagnostic labelling and the emergence of research instruments on which patients with cognitive impairments who show signs of social impairment, but who would previously have had other diagnosis, come up as meeting the criteria for ASD [7],

It is unclear whether the incidence of Kanner autism has changed. It is also unclear whether the net of new instruments hauls in cases of FASD, FACS or FVS not recognized as such, and where in these cohorts children affected by maternal gestational SSRI intake might sit.

ASD is not a traditional disease entity. Against this background it seems prudent to broaden the scope any investigation to look not just at ASD but also at neurodevelopmental delay and perhaps neurodevelopmental spectrum disorders.

It also seems appropriate to broaden the investigation to all domains that might shed light on any assessment of the likelihood of a true association: human epidemiological studies, animal studies and evidence supporting the biological plausibility of a link. A combination of these domains is of importance where the association has serious implications.

\subsection{Biological plausibility}

As regards a linkage between antidepressant use and neurodevelopmental issues, serotonin is notably the most primitive of neurotransmitters; it has a role in early reproduction, and as a result it has long been recognized that acting on serotonin during the gestational period has the potential to cause significant problems $[8,9]$.

In 1960, linked to studies of the effects of antidepressants on serotonin, Ashcroft suggested that there might be a lowering of serotonin in depression [10]. By 1970, Ashcroft and others had discounted this link [11].

In contrast in 1961, a first report was published of elevated serotonin levels in autism [12]. This finding has been consistently replicated since [13-15].

In the early 1960s, a first linkage was made between serotonin and birth defects in animal studies [16-18]. In the early 1970s the first reports linking serotonin reuptake inhibiting antidepressants to birth defects appeared [19]. In 1990, the first independent study linking SSRI intake to teratogenic potential in animal studies was published [20].

As of the 1980s, following descriptions of Fetal Anticonvulsant Syndrome (FACS) and Fetal Valproate Syndrome (FVS), characterized by prominent deficits in social communication and other ASD features [21, 22], a consensus emerged that psychotropic drugs could produce behavioral teratological effects even if they did not show clear anatomical abnormalities such as cardiac or neural tube abnormalities after use during pregnancy [23].

These developments led companies producing novel centrally acting drugs in the 1980s, including SSRIs, to undertake animal studies. In the case of the SSRIs, the animal studies looked at embryo- 
lethality and gross malformations, but an associated objective was to investigate the behavior of neonatal pups. Many of these company studies show a dose related fetal death and other features consistent with a teratogenic capability. The existence of these studies designed to look for evidence of behavioral consequences of SSRI intake during pregnancy for the most part remains unknown with the studies unpublished and the data inaccessible.

There is however a growing set of independent animal studies demonstrating birth defects linked to SSRI use with a range of mechanisms that may underpin these effects [24].

Consistent with these studies and mechanisms, a series of epidemiological studies from 1998 onwards have demonstrated that SSRIs come with a teratogenic potential [25-52]. These findings are summarized in Healy et al. [53] and Berard et al. [24].

Finally published animal studies consistently show that pups born to animals administered antidepressants during pregnancy show a range of behavioral changes indicative of reduced social confidence and communication deficits consistent with a diagnosis of neurodevelopmental spectrum disorders in humans [54-61].

\subsection{Objectives}

Question: Is there evidence to suggest a link between maternal ingestion of SSRI antidepressants during pregnancy and later effects on measures of cognitive function that may lead to diagnoses of behavioral deficits in children exposed in utero, primarily a diagnosis of ASD?

Question: If a link exists, is there evidence from animal intervention studies of a biological mechanisms that might underpin the effect?

\section{Methods}

\subsection{Design}

We carried out a systematic search for all epidemiological studies linking the use of serotonin reuptake inhibiting antidepressants during pregnancy to ASD, and related constructs such as developmental delay or pervasive developmental disorder in offspring. In addition we searched for publications relevant to the range of possible mechanisms through which antidepressant usage might give rise to a diagnosis of ASD in offspring. We followed the MOOSE Guidelines for meta-analyses and systematic reviews of observational studies [62].

\subsection{Search strategy}

We searched Embase, OVID and the Cochrane Library to identify English-language abstracts published up to December 2015. Search terms and strategy were determined by the investigators with advice from a librarian. We applied the following search terms in various combinations which was adapted for each database: Search terms: antidepressants, selective serotonin reuptake inhibitors, SSRIs, pregnancy, autistic spectrum disorder, developmental delay, autism, ADHD, birth defects.

We also hand-searched reference lists of included and excluded articles for articles of potential relevance.

\subsection{Data management}

Abstracts were retrieved and screened and articles determined to be of potential relevance were retained. These articles were screened in detail and articles meeting inclusion criteria were included. 
Each abstract screened and each potentially relevant article retrieved was reviewed independently by two authors (JLN and DM). Discordances were resolved by discussion among the three authors. Review articles were excluded, though references were hand searched for other relevant original data-containing studies.

Abstracts were included for analysis (human) if they satisfied the following inclusion criteria:

- Provided exposure data on gestational SSRI use

- Provided quantitative measures of cognitive behavioral or developmental function in the children exposed in utero

- Controlled for exposure to other potentially teratogenic medications

Abstract were included for analysis (animal) if they

- Provided data on gestational antidepressant use

- Provided quantitative measures relevant to cognitive behavioral or developmental outcomes

We did not restrict by study design but quantitative results had to be available. We excluded articles where we could not obtain an English translation, review articles, and studies where we had abstracts.

Data from included articles were extracted using a standardized form describing the following study characteristics: year, target population, location, sample size, study design, outcome measure, knowledge gaps, key conclusions and study setting. We assessed for duplicate citations and tools.

Where the data on outcomes was available within the published study, we abstracted it from each of these studies. Where the data was not available, we wrote to the authors to request it.

\subsection{Statistical analyses}

All analyses were conducted using Review Manager 5.2 (Copenhagen: The Nordic Cochrane Centre, The Cochrane Collaboration, 2012).

We performed two main analyses, one assessing the association between maternal SSRI use in pregnancy and ASD and the other assessing the association between maternal SSRI use in pregnancy and other neurodevelopmental abnormalities related to autism.

There are methodological issues in plotting these data. In studies looking at children, some less than a year old, it is only possible to look at developmental delay rather than at outcomes that by consensus point to specific failures of social communication rather than cognitive impairment in general. Some studies present outcomes across a range of soft neurological indicators (up to 10 in one study). In order to plot the data, it is necessary therefore to take a representative measure from each study to include in the forest plot. This has been outlined in the appended tables. All data are available from the authors which will permit others to enter different data sets into the plot, as indicated.

\section{Results}

The flow chart (Fig. 1) shows the study search results. Our search retrieved 112 citations of which 67 were potentially relevant abstracts. Of these 67 abstracts screened, 38 articles fit the inclusion criteria. Of these 27 were human studies and 11 were animal studies. Suitable data was available for abstraction in the papers from 21 studies and included in the human dataset. We did not receive responses for requests for data from the three Motherisk studies [64-66] and Suri et al. [67]. Casper et al. [68] and Galbally et al. [69] indicated an inability to access the data at the time it was requested.

Eleven animal studies were identified with adequate data for abstraction from the published papers. 


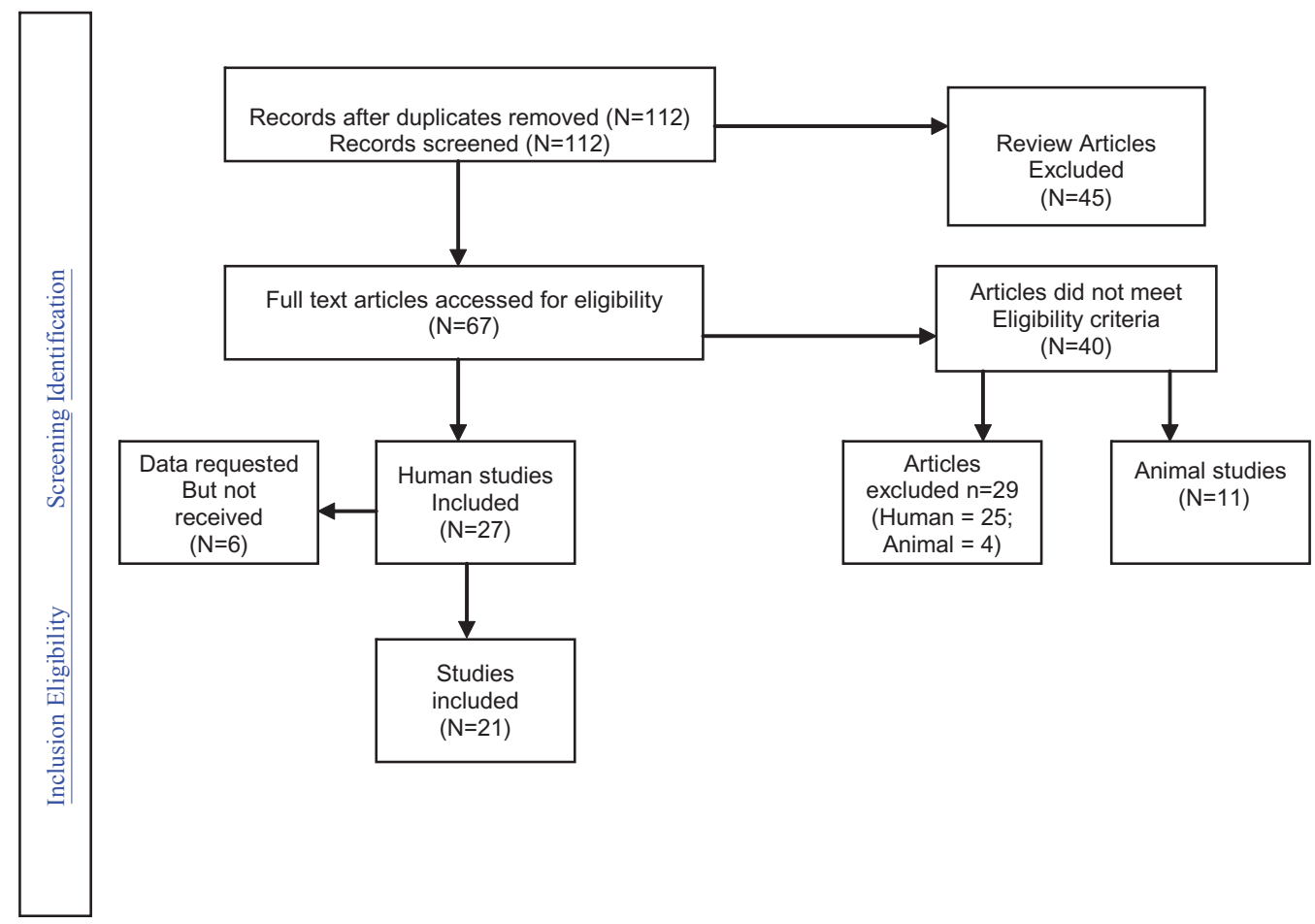

Fig. 1. Outline of search results for human epidemiology studies.

Human study participant size ranged from 36 to $654,000.16$ of the 21 studies included in the analysis used a cohort design and 5 were case controlled.

Most of the included studies point to a linkage between SSRIs and ASD, with almost all published studies pointing to increases in risk even if in individual studies the increase is not significant [68-83].

Some studies reported they found no increase in risk [64-66], however data was not available from the publications of these studies and a request for data to the authors received no response.

A study by Malm and colleagues has found that women taking SSRIs show a 10 fold greater incidence of Fetal Alcohol Spectrum Disorders (FASD) compared with women not on SSRIs [43]. These findings are supported by adverse event reports of FASD and behavioral effects consistent with FASD to FDA for all SSRIs and reports of SSRIs causing compulsive alcohol intake [84]. The Malm findings suggest other studies should look for this clinical syndrome which overlaps with ASD and in particular should not discount the effects of alcohol intake as a confounder.

The results of the individual case-control epidemiological studies as well as the combined effect and statistics are presented in Fig. 2 (see Table 1 also).

\begin{tabular}{|c|c|c|c|c|c|c|c|c|c|c|}
\hline \multirow[b]{2}{*}{ Study or Subgroup } & \multicolumn{2}{|c|}{ Experimental } & \multicolumn{2}{|c|}{ Control } & \multicolumn{3}{|c|}{ Odds Ratio } & \multirow{2}{*}{\multicolumn{3}{|c|}{$\begin{array}{c}\text { Odds Ratio } \\
\text { M-H, Random, } 95 \% \mathrm{Cl}\end{array}$}} \\
\hline & Events & Total & Events & Total & Weight & M-H, Random, 95\% Cl & Year & & & \\
\hline Croen et al 2011 & 15 & 298 & 34 & 1507 & $8.5 \%$ & $2.30[1.23,4.27]$ & 2011 & & $\longrightarrow$ & \\
\hline Rai et al 2013 & 14 & 1679 & 71 & 16845 & $9.9 \%$ & $1.99[1.12,3.53]$ & 2013 & & $\longrightarrow$ & \\
\hline Clements et al 2014 & 40 & 1377 & 80 & 4022 & $22.2 \%$ & $1.47[1.00,2.17]$ & 2014 & & $-\infty$ & \\
\hline Harrington et al 2014 & 29 & 492 & 11 & 320 & $6.5 \%$ & $1.76[0.87,3.57]$ & 2014 & & $\longrightarrow$ & \\
\hline Gidaya et al 2014 & 76 & 5067 & 365 & 52143 & $52.9 \%$ & $2.16[1.68,2.77]$ & 2014 & & 늘 & \\
\hline Total $(95 \% \mathrm{Cl})$ & & 8913 & & 74837 & $100.0 \%$ & $1.95[1.63,2.34]$ & & & 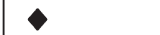 & \\
\hline Total events & 174 & & 561 & & & & & & & \\
\hline $\begin{array}{l}\text { Heterogeneity: } \operatorname{Tau}^{2}= \\
\text { Test for overall effect: }\end{array}$ & $\begin{array}{l}.00 ; \mathrm{Chi}^{2} \\
=7.24(\mathrm{P}\end{array}$ & $\begin{array}{l}3.06, d \\
0.000\end{array}$ & $f=4(P=$ & $0.55) ;$ & $=0 \%$ & & & $\begin{array}{ccc}0.01 & 0.1 \\
& \text { Favours [experimental] }\end{array}$ & $\begin{array}{lc}10 \\
\text { Favours [control] }\end{array}$ & 100 \\
\hline
\end{tabular}

Fig. 2. Analysis of Case Controlled Studies. 
Table 1

Notes for Fig. 2 forest plot

\begin{tabular}{|c|c|c|c|}
\hline Authors & Type of antidepressants & Study Outcome & Additional analyses available \\
\hline Croen et al. 2011 & $\begin{array}{l}\text { SSRIs (citalopram, } \\
\text { fluoxetine, fluvoxamine, } \\
\text { paroxetine, sertraline,) }\end{array}$ & Prenatal exposure to SSRI & $\begin{array}{l}\text { Additionally looked at } \\
\text { 'exposure to ANY } \\
\text { antidepressant' } \\
(\mathrm{OR}=2.10, \mathrm{CI} 1.23-3.58) \text {. }\end{array}$ \\
\hline Rai et al. 2013 & $\begin{array}{l}\text { SSRIs (fluoxetine, } \\
\text { citalopram, paroxetine, } \\
\text { sertraline). }\end{array}$ & ASD diagnosis. & $\begin{array}{l}\text { Figures also available for 'all } \\
\text { antidepressants' and risk of } \\
\text { ASD: }(\mathrm{OR}=2.27, \mathrm{CI} \text { : } \\
\text { 1.4-3.71). }\end{array}$ \\
\hline Harrington et al. 2014 & $\begin{array}{l}\text { SSRIs (Fluoxetine, sertraline, } \\
\text { paroxetine, citalopram, } \\
\text { escitalopram). }\end{array}$ & Prenatal exposure to SSRI & $\begin{array}{l}\text { Additionally looked at } \\
\text { children with } \\
\text { developmental delay vs } \\
\text { controls. }\end{array}$ \\
\hline Clements et al. 2014 & $\begin{array}{l}\text { All Antidepressants (High } \\
\text { affinity - paroxetine, } \\
\text { duloxetine, sertraline, } \\
\text { escitalopram, fluoxetine; } \\
\text { Moderate affinity } \\
\text { - citalopram, fluvoxamine, } \\
\text { venlafaxine; Low affinity - } \\
\text { nefazodone, bupropion, } \\
\text { mirtazapine) }\end{array}$ & $\begin{array}{l}\text { Prenatal exposure to } \\
\text { antidepressants }\end{array}$ & $\begin{array}{l}\text { Additionally looked at } \\
\text { children with ADHD vs } \\
\text { controls (OR=1.67, CI } \\
\text { 1.67-3.34) -see Fig. 3a } \\
\text { and } 3 \mathrm{~b} \text {. }\end{array}$ \\
\hline Gidaya et al. 2014 & $\begin{array}{l}\text { SSRIs (fluoxetine, } \\
\text { citalopram, paroxetine, } \\
\text { sertraline, fluvoxamine, } \\
\text { escitalopram). }\end{array}$ & Prenatal exposure to SSRI & \\
\hline
\end{tabular}

Figure $3 \mathrm{a}$ and $3 \mathrm{~b}$ outline the effects on other neurodevelopmental outcomes (see Table 2 also). Figure 3a includes the Malm FASD figures. Figure 3b offers the same data with Malm excluded.

\subsection{Potential mechanisms}

In terms of the effects of antidepressants on neurodevelopment, we have abstracted a range of mechanisms through which gestational SSRIs might impact on cognitive function that recent literature supports.

First, as noted above serotonin has a role in embryogenesis and there is convincing evidence that disturbing this function leads to defects in many systems from cardiac through to neurological [24]. In addition to evidence for gross birth defects, there has been evidence from animal studies for over a decade that SSRIs can lead to abnormalities in cerebral architecture [85-87]. We have not found any studies demonstrating normal brain architecture. These changes appear linked to reduced exploratory behavior and reduced reactivity [88].

Second, SSRIs have profound effects on sexual behavior and this can be expected to have longer term consequences in the social domain $[55,56,89]$.

Third, SSRIs can induce compulsive alcohol intake [84] and this might be expected to make some contribution to the epidemiological picture. The study by Malm et al. [43] suggests it does. 


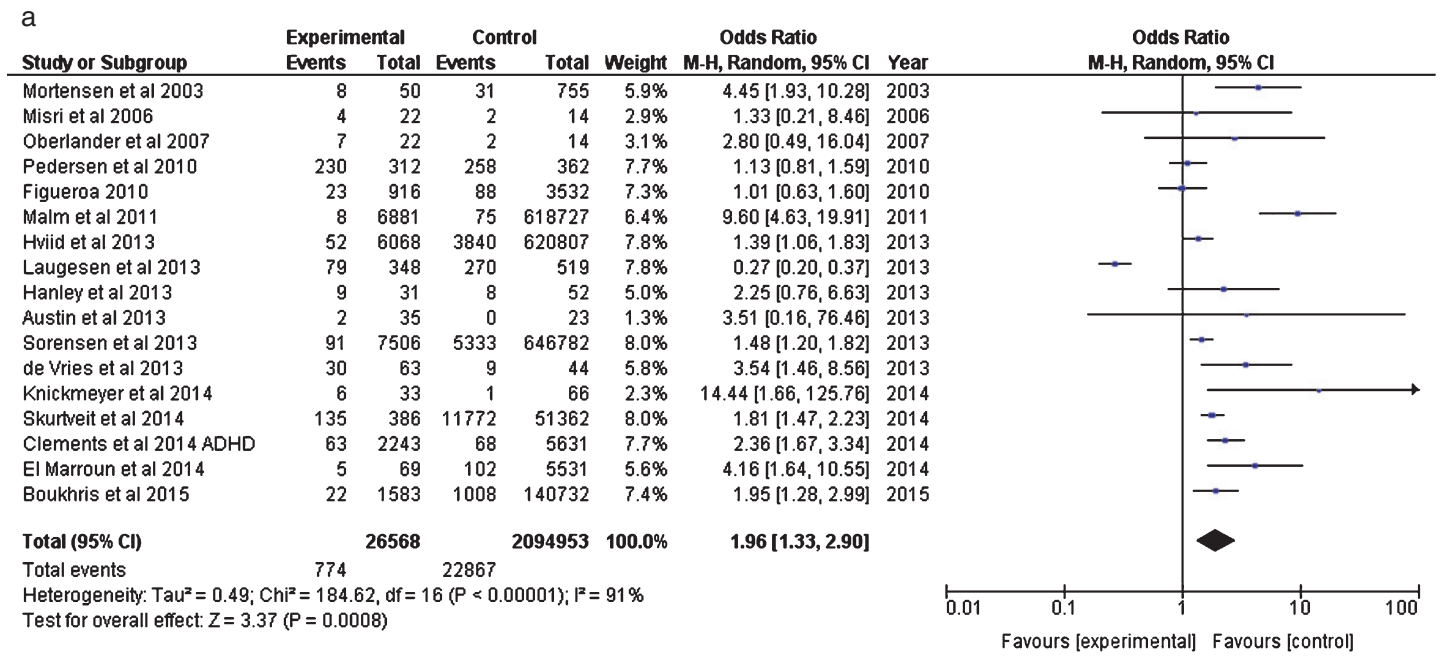

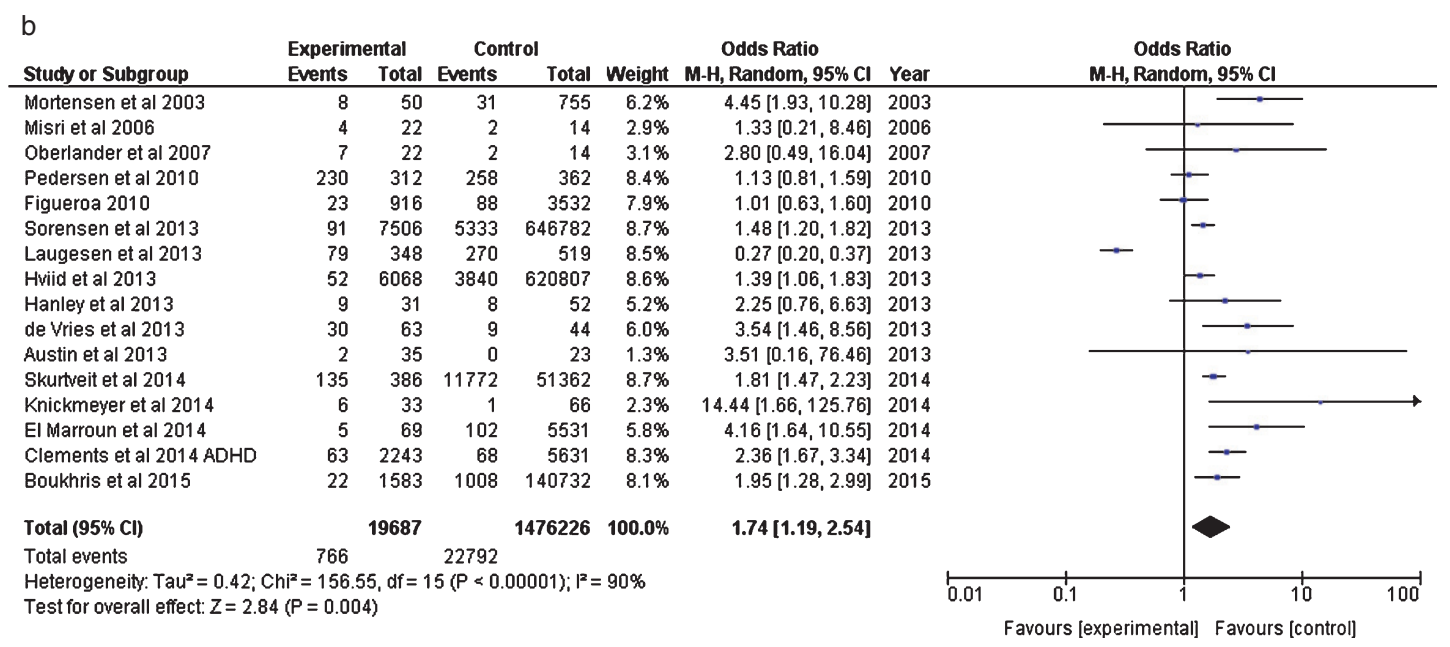

Fig. 3. (a) Analysis of Prospective Cohort Studies (including Malm et al. 2011, FAS data). (b) Analysis of Prenatal Prospective Cohort Studies (excluding Malm et al. 2011, FAS).

Fourth, a noted feature of SSRIs is that they produce the experience of blunted emotion [90]. Linked to this it would appear, they lead to decrements in our abilities to read emotion [91]. These behavioral effects are consonant with changes that will register on instruments currently used to detect communication difficulties and are likely to lead to an ASD diagnosis.

This point has become of greater interested in the light of evidence linking acetaminophen (paracetamol) to ASD [92]. While the link here might arise indirectly, if acetaminophen is used to treat a fever, this medicine also appears to have comparable effects to SSRIs on sociability in animals [93] and on the ability of people to read emotions [94]. Acetaminophen also has effects on S-1 receptors so there is a considerable overlap in its mechanism of actions with SSRIs.

Both acetaminophen and SSRIs may therefore mediate their effects through end-stage behavioral changes. These behavioral changes can endure for months after treatment stops in adults. If administered in utero, one possibility is that such changes may be even more likely to endure and produce an ASD clinical picture.

Fifth, given that current diagnoses of ASD may include children with general cognitive problems rather than specific disturbances of a discrete communication function, a range of treatment related fac- 
Table 2

Notes forest plot (Fig. 3a \& 3b)

\begin{tabular}{|c|c|c|c|}
\hline Authors & Type of antidepressants & Study Outcome & Additional analyses available \\
\hline Mortensen et al. 2003 & $\begin{array}{l}\text { All antidepressants } \\
\text { (breakdown not specified) } \\
\text { authors emailed } 29.04 .15 \text { to } \\
\text { verify. }\end{array}$ & $\begin{array}{l}\text { Abnormal psychomotor } \\
\text { development (Boel test) at } \\
7-10 \text { months }\end{array}$ & $\begin{array}{l}\text { Exposure also to } \\
\text { anti-epileptics, neuroleptics } \\
\text { and benzos. }\end{array}$ \\
\hline Misri et al. 2006 & $\begin{array}{l}\text { SSRIs (fluoxetine, paroxetine, } \\
\text { sertraline) }\end{array}$ & $\begin{array}{l}\text { Internalising behaviour } \\
\text { (depression, anxiety, } \\
\text { withdrawal) at } 4 \text { years } \\
\text { (Child Behaviour Checklist } \\
\text { composite scores) }\end{array}$ & - \\
\hline Oberlander et al. 2007 & $\begin{array}{l}\text { SSRI (breakdown not } \\
\text { specified) }\end{array}$ & $\begin{array}{l}\text { Clinically elevated } \\
\text { externalising scores } \\
\text { (attention, aggression, } \\
\text { ADHD, ODD) at age } 4 \\
\text { years. }\end{array}$ & - \\
\hline Figueroa 2010 & $\begin{array}{l}\text { SSRI (breakdown not } \\
\text { specified). }\end{array}$ & $\begin{array}{l}\text { ADHD diagnosis at age } 5 \\
\text { years. }\end{array}$ & - \\
\hline Pedersen et al. 2010 & $\begin{array}{l}\text { All antidepressants (SSRI } \\
\text {-fluoxetine, citalopram, } \\
\text { paroxetine, sertraline; } \\
\text { TCAs; Other e.g. } \\
\text { venlafaxine). }\end{array}$ & $\begin{array}{l}\text { All developmental milestones } \\
\text { at } 6 \text { months combined (i.e. } \\
\text { motor, attention, cognition, } \\
\text { language) }\end{array}$ & - \\
\hline Malm et al. 2011 & $\begin{array}{l}\text { SSRIs (Fluoxetine, sertraline, } \\
\text { paroxetine, citalopram, } \\
\text { escitalopram). }\end{array}$ & $\begin{array}{l}\text { Foetal alcohol spectrum } \\
\text { disorders (FAS) }\end{array}$ & - \\
\hline Hviid et al. 2013 & $\begin{array}{l}\text { SSRI (breakdown not } \\
\text { specified) }\end{array}$ & ASD diagnosis & - \\
\hline de Vries et al. 2013 & $\begin{array}{l}\text { SSRIs Fluoxetine, sertraline, } \\
\text { paroxetine, citalopram) plus } \\
\text { venlafaxine (low dose). }\end{array}$ & $\begin{array}{l}\text { Monotonous movements at } \\
\text { 3-4 months }\end{array}$ & $\begin{array}{l}\text { Figures also available for } \\
\text { General movements during } \\
\text { first week after birth } \\
(\mathrm{OR}=3.04, \mathrm{CI}: 1.33,6.91) \text {. }\end{array}$ \\
\hline Austin et al. 2013 & $\begin{array}{l}\text { SSRIs (Fluoxetine, sertraline, } \\
\text { paroxetine, citalopram, } \\
\text { escitalopram, venlafaxine, } \\
\text { fluvoxamine, dothiepin). }\end{array}$ & $\begin{array}{l}\text { Motor development (Bayley } \\
\text { composite scores) at } 18 \\
\text { months: }\end{array}$ & $\begin{array}{l}\text { Figures also available for } \\
\text { cognitive development } \\
(\mathrm{OR}=5.06, \mathrm{CI} \text { : } \\
0.25-102.72) \& \text { language } \\
\text { development }(\mathrm{OR}=2.84, \\
\text { CI: } 0.30-27.16) 18 \text { months. }\end{array}$ \\
\hline Hanley et al. 2013 & SRIs & $\begin{array}{l}\text { Neurodevelopment at } 10 \\
\text { months (Bayley } \\
\text { scale)-Gross motor. }\end{array}$ & $\begin{array}{l}\text { Figures also available for fine } \\
\text { motor, cognitive, } \\
\text { communication, } \\
\text { social-emotional and } \\
\text { adaptive behaviours. }\end{array}$ \\
\hline Laugesen et al. 2013 & $\begin{array}{l}\text { All antidepressants } \\
\text { (breakdown not specified) }\end{array}$ & $\begin{array}{l}\text { ADHD diagnosis at age } 8 \\
\text { years. }\end{array}$ & - \\
\hline
\end{tabular}


Table 2

(Continued)

\begin{tabular}{|c|c|c|c|}
\hline Authors & Type of antidepressants & Study Outcome & Additional analyses available \\
\hline Sorensen et al. 2013 & $\begin{array}{l}\text { SSRI (breakdown not } \\
\text { specified) }\end{array}$ & ASD diagnosis. & $\begin{array}{l}\text { Figures also available for 'all } \\
\text { antidepressants' and risk of } \\
\text { ASD } \\
\text { (OR=1.43, CI: } 1.18-1.74) \text {. } \\
\text { In addition authors looked at } \\
\text { SSRIs exposure and } \\
\text { exposure to all } \\
\text { antidepressants and risk of } \\
\text { autism. }\end{array}$ \\
\hline Clements et al. 2014 & $\begin{array}{l}\text { All Antidepressants (High } \\
\text { affinity - paroxetine, } \\
\text { duloxetine, sertraline, } \\
\text { escitalopram, fluoxetine; } \\
\text { Moderate affinity - } \\
\text { citalopram, fluvoxamine, } \\
\text { venlafaxine; Low affinity - } \\
\text { nefazodone, bupropion, } \\
\text { mirtazapine) }\end{array}$ & $\begin{array}{l}\text { Prenatal exposure to } \\
\text { antidepressants and risk of } \\
\text { ADHD. }\end{array}$ & - \\
\hline Knickmeyer et al. 2014 & $\begin{array}{l}\text { SSRIs (Sertraline, fluoxetine, } \\
\text { citalopram, paroxetine). }\end{array}$ & $\begin{array}{l}\text { Chiari I malformations 1-2 } \\
\text { years }\end{array}$ & - \\
\hline El Marroun et al. 2014 & $\begin{array}{l}\text { SSRIs (Fluoxetine, sertraline, } \\
\text { paroxetine, citalopram, } \\
\text { fluvoxamine). }\end{array}$ & $\begin{array}{c}\text { Pervasive developmental } \\
\text { problems at } 1.5 \text { years }\end{array}$ & Figures also available at 6 yrs. \\
\hline Skurtveit et al. 2014 & $\begin{array}{l}\text { SSRI (breakdown not } \\
\text { specified) }\end{array}$ & $\begin{array}{l}\text { Not achieving best language } \\
\text { competence category (long } \\
\text { complicated sentences) at } \\
\text { age } 3 \text { years }\end{array}$ & - \\
\hline Boukhris et al. 2015 & $\begin{array}{l}\text { SSRI used in Forest plots } \\
\text { (Figs. } 2 \text { and } 3 \text { ). }\end{array}$ & $\begin{array}{l}\text { ASD diagnosis (following } \\
\text { exposure during } 2 \mathrm{nd} / 3 \mathrm{rd} \\
\text { trimester). }\end{array}$ & $\begin{array}{l}\text { All antidepressants (also } \\
\text { breakdown given for type - } \\
\text { SSRI, SNRI, MAOI, } \\
\text { tricyclic and others). }\end{array}$ \\
\hline
\end{tabular}

tors from SSRI withdrawal to postnatal operative interventions to correct birth defects may contribute to the potential of these drugs to give rise to ASD clinical pictures.

Finally when considering these mechanisms it would be a mistake to focus solely on a supposed ASD. It is important to establish the full range of effects these drugs have and there is emerging but as yet unpublished literature that rates of ADHD for instance may be increased in children born to mothers on SSRIs. Any mechanisms proposed need to be able to account for such changes also.

\section{Discussion}

The Forest plots show the consistency of the findings to date. Whether looking at a strict diagnosis of ASD, including just case-control or all observational studies or assessing other neurodevelopmental outcomes, SSRIs have a consistent pattern of association with poorer outcomes. The increase in rates of developmental delay linked to SSRI use in pregnancy may also be consistent with increased rates 
of diagnoses of ASD in the offspring of women exposed to these treatments. It is unclear what this linkage means. Some of the data may reflect dyspraxia or related soft neurological signs that need not necessarily be accompanied by cognitive or social impairments, and may disappear in later life.

These findings are supported by consistent findings in the animal studies reviewed, and by the existence of a number of biologically plausible mechanisms in humans.

This review builds on previous reviews by Gentiles [95] and Mann et al. [96]. Gentiles provided a narrative review of the evidence, though did not perform a meta-analysis. In contrast to Mann et al. we have included two important studies in the review [70, 73] and included meta-analysis or and review of studies of other neurodevelopmental outcomes as well as systematically reviewing quantitative evidence from animal studies.

There is moreover a range of mechanisms through which the effects of SSRIs might lead to outcomes attracting an ASD diagnosis. To move our understanding forward will require a consideration of both epidemiological findings and physiological studies. The reason to review these physiological mechanisms is that the epidemiological evidence is at a point where it is now clear that greater specificity in clinical phenotypes is needed in order to make sense of possible links between treatment and outcomes.

The state of the developing science maps onto the respective roles of epidemiology and biology in elucidating the risk of birth defects on doxylamine (Bendectin). Doxylamine is used for nausea in pregnancy. In the 1970s it was linked to cardiac and limb defects [97]. However several early epidemiological studies cast doubt on the link between doxylamine and birth defects [98-101].

Reviewing all epidemiology studies on doxylamine, it is clear that while many studies show no increase in risk, a majority show some increase in risk compared with non-treatment [102-114].

There is now a greater understanding of the critical time periods when drugs can lead to cardiac and other defects, making it clear that the epidemiological findings must be interpreted against a background that recognizes that women rarely start taking doxylamine before week 6-8 and by this time the risk of cardiac defects has all but been eliminated [115]. This fact makes any increase in risk notable.

There is a further background. Doxylamine is an anti-histamine. There appears to be an increased risk of birth defects on serotonin reuptake inhibiting antihistamines, such as doxylamine, compared to non-serotonin reuptake inhibiting antihistamines [116] and similarly an increase in risk on serotonin reuptake inhibiting antidepressants, not found in antidepressants that are inactive on the serotonin system [53, 117].

Because doxylamine intake starts relatively late in the first trimester, epidemiological studies while indicating it is unlikely to cause birth defects may on their own be unable to settle the question as to whether it has a potential to cause birth defects. In making a judgment as to whether this drug poses risks, biological evidence is informative, although it also has its limitations.

As the case of acetaminophen indicates, we do not at this point know whether the physiological effects of serotonin reuptake inhibiting drugs on developmental delay are mediated at a molar level altering our social perceptions or at an ionic level. Gross cardiac defects might be linked to changes in sodium ion flow for instance with behavioral effects stemming from cognitive effects of the drugs.

There is a need for the epidemiology to remain biologically informed and for biologists to be aware that diagnoses of ASD and the instruments used in epidemiological studies might mislead them as to what physiological factors should be explored further. Nothing better illustrates this than the evidence from Malm et al. study [43], which is consistent with known effects of SSRIs in triggering alcohol intake in a sub-population of subjects and a recent RCT showing poorer drinking outcomes with citalopram treatment for alcohol dependence disorder [118].

This Malm study also indicates that while it has been routine to adjust for confounders such as alcohol intake that such adjustments may be mistaken in the case of serotonin reuptake inhibiting 
antidepressants with SSRIs having effects on both alcohol and nicotine intake as well as glucose levels.

\subsection{SSRIs in pregnancy}

For SSRI usage to have played a part in increasing rates of ASD, we would expect there to be evidence that there has likely been an increase in the use of these drugs in women of childbearing years and a more relaxed medical and public attitude about the use of these drugs during pregnancy.

Unlike earlier antidepressants where the market was largely in older age groups, it was clear that a large part of the market for SSRIs would be to women of child-bearing years.

In the early 1990s when the SSRIs were marketed first, the prevailing wisdom was that giving psychotropic drugs in pregnancy was to be avoided; regulators supported avoidance [119], professional bodies supported avoidance [120], and leading psychiatrists warned of the teratogenic potential of psychotropic drugs [121-123].

There was not thought to be any increase in the incidence of mood disorder during pregnancy [124]. There was not thought to be any risk from mood disorders to the fetus; the risk from mood disorders lay in the risk posed to the mother such as suicide [125].

In contrast today it is common to hear claims that depression directly or indirectly causes birth defects; to see a conflation of depressive symptoms with depressive illnesses, so that rates of 15-20\% for depressive disorders are cited when this should only apply to depressive symptoms [53]; and it is not widely noted that the majority of states treated with these drugs left untreated clear up spontaneously within weeks.

In 2015, in the absence of any intervening data that depression causes birth defects or that SSRIs are effective in antenatal depression, it is possible to find the same authors who advocated caution about the use of antidepressants in the early 1990s, supporting claims that:

- Depression can cause birth defects [126]

- Antidepressants do not cause birth defects or cognitive problems [127]

- That coming off antidepressants is inadvisable [128]

- Professional bodies endorse the use of antidepressants [129]

If SSRIs work, as claimed by marketing, namely by correcting a serotonergic abnormality it might be thought they would reduce the risk of things going wrong. But there is no such abnormality and treatment with an SSRI on balance will leave serotonin systems more abnormal that they were to begin with [130].

If working means that SSRIs reduce risky behaviors including alcohol and drug intake, the evidence is somewhat to the contrary; SSRIs may increase alcohol and drug use [84, 131].

\subsection{Alternative explanations}

Concerns about a link between SSRIs and birth defects have met the following counter arguments that are as readily applicable here.

First, rates of ASD from these studies, as is the case with rates of birth defects on SSRIs, fall within the background rate of the population at large and on this basis it is claimed that even where the rates in the treated group exceed those in the control group, these rates can be discounted [see 128, 132]. This argument is not valid for birth defect studies where the background rate is determined by the study design. The argument is misplaced for a condition like ASD or neurodevelopmental spectrum disorders where the background rate appears to be changing by the year. 
Second, studies of SSRI use during pregnancy show a consistent rate of problems and that when all studies are meta-analyzed the risks disappear. We have not been able to analyze all studies as some groups, such as the Motherisk group, refuse to share their data.

Third, it is claimed that depression causes both birth defects and ASD and is endemic in pregnant women at rates of $15-20 \%$. We believe there is no good evidence for these propositions.

Fourth, it is proposed that there are no adequate and well-conducted studies in this area. This statement means that there are no RCTs and assumes the reader will accept the proposition that only RCTs can demonstrate if an antidepressant causes birth defects or ASD or not. In our opinion this position is incorrect. RCTs can get the answer as badly wrong as any other epidemiological study [see 133]. To establish what is happening will need judgements that take both the epidemiological and biological data into account. It is only when there is a good understanding of what is happening that an appropriate RCT can be designed.

Finally, it is claimed that the results cited from a majority of studies show no statistically significant difference between women treated and those not treated. For some if an increase in risk is not significant, they take a view that there is in fact no increase in risk. This is not the most widely accepted view in the field [134]. The visual plots of the meta-analyses demonstrate this point clearly.

\section{Conclusion}

ASD is at present an amorphous entity and has some roots in classic autism but now appears to encompass areas formerly termed learning disabilities or developmental delay. Across this spectrum there is evidence that the intake of serotonin reuptake inhibiting drugs may lead to poorer outcomes, although little clarity at present as to the most likely mechanisms involved.

Further progress in this area will require greater precision in terms of clinical phenotypes and efforts to control for intervening variables such as operative interventions for birth defects or alcohol intake in pregnancy.

The area calls out for the establishment of comprehensive pregnancy registries.

\section{Conflict of interest}

DH and DM are potential expert witnesses in a case involving SSRIs and ASD but this case arose toward the date of completion of this article. JLN has no competing interests as regards the subject matter of this study.

\section{Author contributions}

Prof David Healy: principal investigator and primary author;

Dr Joanna Le Noury: data collection, analysis, study write up and review;

Prof Dee Mangin: data collection, analysis, study write up and review.

\section{References}

[1] Kanner L. Autistic disturbances of affective content. The Nervous Child. 1943;2:217-50.

[2] Lotter V. Epidemiology of autistic conditions in young children. Social Psychiatry Research Unit. 1966;124-37.

[3] Torrey EF, Hersh S, McCabe K. Early childhood psychosis and bleeding during pregnancy. J of Autism and Childhood Schizophrenia. 1975;5:287-97.

[4] Wing L. Autistic Spectrum Disorders. BMJ. 1996;312:327. 
[5] Baron-Cohen S, Scott F, Allison C, Williams J, Bolton P, Matthews F, Brayne C. Prevalence of autism-spectrum conditions: UK school-based population study. British Journal of Psychiatry. 2009;194:500-9.

[6] Baio J. Prevalence of autism spectrum disorder among children aged 8 years-autism and developmental disabilities monitoring network. Surveillance Summaries. 2014;63(SS02):1-21.(ASD Data and Statistics. CDC.gov-http://www.cdc.gov/media/releases/2014/p0327-autism-spectrum-disorder.html)

[7] Hansen SN, Schendel DE, Parner ET. Explaining the increase in the prevalence of Autism spectrum disorders. The proportion attributable to changes in reporting practices. JAMA Pediatr. 2015;169:56-62.

[8] Buznikov G, Sakharova A, Manukhin B, Markova L. The role of neurohumours in early embryogenesis IV. Fluorometric and histochemical study of serotonin in cleaving eggs and larvae of sea urchins. J Embryol Exp Morphol. 1972;27:339-51.

[9] Buznikov GA. The action of neurotransmitters and related substances on early embryogenesis. Pharmacol Ther. 1984;25:23-59.

[10] Ashcroft GW, Sharman DF. 5-Hydroxyindoles in human cerebrospinal fluids. Nature. 1960;186:1050-1.

[11] Ashcroft GW. The Receptor enters Psychiatry. In: Healy D. The Psychopharmacologists, Volume 3. Arnold, London; 2000;189-200.

[12] Schain R, Freedman DX. Studies on 5-hydroxyindole metabolism in autistic and other mentally retarded children. J of Pediatrics. 1961;58:315-20.

[13] Hanley HG, Stahl SM, Freedman DX. Hyperserotonemia and Amine Metabolites in Autistic and Retarded Children. Arch Gen Psychiatry. 1977;34:521-31.

[14] Ritvo ER, Freeman B, Yuwiler A, Geller E, Yokola A, Schroth P, Novak P. Study of fenfluramine in outpatients with the syndrome of autism. J Pediatrics. 1984;105:823-28.

[15] Burgess N, Sweeten T, McMahon W. Hyperserotoninemia and altered immunity in autism. J Autism Dev Disorders. 2006;36:697-704.

[16] Reddy DV, Adams FH, Baird C. Teratogenic effects of serotonin. J Pediatr. 1963;63:394-7.

[17] Poulson E, Robson J, Sullivan F. Teratogenic effect of 5-hydroxytryptamine in mice. Science. 1963;141:717-8.

[18] Marley PB, Robson J, Sullivan F. Embryotoxic and teratogenic action of 5-hydroxytryptamine: Mechanism of action in the rat. Br J Pharmacol Chemother. 1967;31:494-505.

[19] McBride WG. Limb deformities associated with iminodibenzyl hydrochloride. Med J Aust. 1972;1:492.

[20] Shuey DL, Yavarone M, Sadler T, Lauder J. Serotonin and morphogenesis in the cultured mouse embryo. Adv Exp Med Biol. 1990;265:2015-215.

[21] Hanson JW, Smith DW. The Fetal Hydantoin syndrome. J Pediatrics. 1975;87:285-90.

[22] Smith DW. Teratogenicity of anticonvulsive medications. Am J Dis Child. 1997;131:1337-9.

[23] Vorhees CV, Butcher RE. Behavioral teratogenicity. In: Snell K. Developmental Toxicology. Praeger, New York; 1988;249-98.

[24] Bérard A, Levin M, Sadler T, Healy D. SSRI use during pregnancy and major malformations: The importance of serotonin for embryonic development and the effect of serotonin inhibition on the occurrence of malformations. Reproductive Toxicology. 2015; (in press).

[25] Kulin NA, Pastuszak A, Sage SR, Schick-Boschetto B, Spivey G, Feldkamp M, Ormond K, Matsui D., SteinSchechman AK, Cook L, Brochu J, Rieder M, Koren G. Pregnancy outcome following maternal use of the new selective serotonin reuptake inhibitors: A prospective controlled multicenter study. JAMA. 1998;279:609-10.

[26] Chambers CD, Dick LM, Felix RJ, Johnson KA, Jones KL. Pregnancy outcome in women who use sertraline [abstract]. Teratology. 1999;59:376.

[27] Diav-Citrin O, Shechtman S, Weinbaum D, Arnon J, Wajnberg R, Ornoy A. Pregnancy outcome after gestational exposure to paroxetine: A prospective controlled cohort study. Teratology. 2002;65:298.

[28] Kallen B, Otterblad Olausson P. Maternal drug use in early pregnancy and infant cardiovascular defect. Reprod Toxicol. 2003;17:255-61.

[29] Malm H, Klaukka T, Neuvonen PJ. Risks Associated with Selective Serotonin Reuptake Inhibitors in Pregnancy. Obstet Gynecol. 2005;106:1289-96.

[30] Wogelius P, Norgaard M, Gislum M, Pedersen L, Munk E, Mortensen PB, Lipworth L, Sorensen HT. Maternal use of selective serotonin reuptake inhibitors and risk of congenital malformations. Epidemiology. 2006;17:701-4.

[31] Alwan S, Reefhuis J, Rasmussen SA, Olney RS, Friedman JM. Use of selective serotonin-reuptake inhibitors in pregnancy and the risk of birth defects. New England Journal of Medicine. 2007;356:2684-92.

[32] Louik C, Lin AE, Werler MM, Hernandez-Diaz S, Mitchell AA. First-trimester use of selective serotonin-reuptake inhibitors and the risk of birth defects. New England Journal of Medicine. 2007;356:2675-83.

[33] Kallen B, Olausson PO. Maternal use of selective serotonin- re-uptake inhibitors and persistent pulmonary hypertension of the newborn. Pharmacoepidemiology and Drug Safety. 2008;17:801-6. 
[34] Oberlander TF, Warburton W, Misri S, Riggs W, Aghajanian J, Hertzman C. Major congenital malformations following prenatal exposure to serotonin reuptake inhibitors and benzodiazepines using population-based health data. Birth Defects Research Part B, Developmental and Reproductive Toxicology. 2008;83:68-76.

[35] Merlob P, Birk E, Sirota L, Linder N, Berant M, Stahl B, Klinger G. Are selective serotonin reuptake inhibitors cardiac teratogens? Echocardiographic screening of newborns with persistent heart murmur. Birth Defects Res A Clin Mol Teratol. 2009;85:837-41.

[36] Pedersen LH, Henriksen TB, Vestergaard M, Olsen J, Bech BH. Selective Serotonin Reuptake Inhibitors in Pregnancy and Congenital Malformations: Population Based Cohort Study, BMJ. 2009;339:b3569.

[37] Bakker M, de Walle H, Wilffert B, de Jong-van den Berg L. Fluoxetine and infantile hypertrophic pylorus stenosis: A signal from a birth defects—drug exposure surveillance study. Pharmacoepidemiology and Drug Safety. 2010;19: 808-13.

[38] Kornum JB, Nielsen RB, Pedersen L, Mortensen PB, Norgaard M. Use of selective serotonin-reuptake inhibitors during early pregnancy and risk of congenital malformations: Updated analysis. Clinical Epidemiology. 2010;2:29-36.

[39] Nakhai-Pour HR, Broy P, Berard A. Use of antidepressants during pregnancy and the risk of spontaneous abortion. CMAJ. 2010;182:1031-7.

[40] Reis M, Kallen B. Delivery outcome after maternal use of antidepressant drugs in pregnancy: An update using swedish data. Psychol Med. 2010;40:1723-33.

[41] Colvin L, Slack-Smith L, Standley FJ, Bower C. Dispensing patterns and pregnancy outcomes for women dispensed selective serotonin reuptake inhibitors in pregnancy. Birth Defects Research Part A; Clinical and Molecular Teratology. 2011;91:142-52.

[42] Malm H, Artama M, Gissler M, Ritvanen A. Selective serotonin reuptake inhibitors and risk for major congenital anomalies. Obstet Gynecol. 2011;118:111-20.

[43] Jimenez-Solem E, Andersen JT, Petersen M, Broedbaek K, Jensen JK, Afzal S, Gislason GH, Torp-Pedersen C, Poulse HE. Exposure to selective serotonin reuptake inhibitors and the risk of congenital malformations: A nationwide cohort study. BMJ. 2012;2:1-9.

[44] Nordeng H, Van Gelder MM, Spigset O, Koren G, Einarson A, Eberhard-Gran M. Pregnancy outcome after exposure to antidepressants and the role of maternal depression. J Clinical Psychopharmacology. 2012;32:186-94.

[45] Margulis AV, Abou-Ali A, Strazzeri MM, Ding Y, Kuyateh F, Frimpong EY, Levenson MS, Hammad TA. Use of selective serotonin reuptake inhibitors in pregnancy and cardiac malformations: A propensity-score matched cohort in CPRD. Pharmacoepidemiol Drug Saf. 2013;22:942-51.

[46] Myles N, Newall H, Ward H, Large M. Systematic meta-analysis of individual selective serotonin reuptake inhibitor medications and congenital malformations. Aust N Z J Psychiatry. 2013;47(11):1002-12.

[47] Huybrechts K, Palmsten K, Avorn J, Cohen LS, Holmes LB, Franklin JM, Mogun H, Levin R, Kowal M, Setoguchi S, Hernandez-Diaz S. Antidepressant use in pregnancy and the risk of cardiac defects. N Engl J Med. 2014;370:2397-407.

[48] Knudsen TM, Hansen AV, Garne E, Andersen AMN. Increased risk of severe congenital heart defects in offspring exposed to selective serotonin-reuptake inhibitors in early pregnancy-an epidemiological study using validated EUROCAT data. BMC Pregnancy and Childbirth. 2014;14:333.

[49] Furu K, Kieler H. Teratogenicity of selective serotonin-reuptake inhibitors and venlafaxine-a population-based study of 2.3 million births in five Nordic countries: Antidepressants during Pregnancy and Diverse Outcomes [oral session] 2014.

[50] Yazdy M, Mitchell A Louik C, Werler M. Use of selective serotonin-reuptake inhibitors during pregnancy and the risk of club foot. Epidemiology. 2014;25:859-65.

[51] Ban L, Gibson JE, West J, Fiaschi L, Sokal R, Smeeth L, Doyle P, Hubbard RB, Tata LJ. Maternal depression, antidepressant prescriptions, and congenital anomaly risk in offspring: A population-based cohort study. BJOG. 2014;121:1471-81. doi: 10.1111/1471-0528.12682

[52] Healy D, Mangin D, Mintzes B. The ethics of randomized placebo controlled trials of antidepressants with pregnant women. Int J of Risk and Safety in Medicine. 2010;22:7-16.

[53] Polleux F, Lauder JM. Toward a developmental neurobiology of autism. Mental Retardation \& Development Disabilities Research Reviews. 2004;10:303-17.

[54] Maciag D, Simpson KL, Coppinger D, Lu Y, Wang Y, Lin RC, Paul IA. Neonatal antidepressant exposure has lasting effects on behaviour and serotonin circuitry. Neuropsychopharmacology. 2006a;31(1):47-57.

[55] Maciag D, Coppinger D, Paul IA. Evidence that the deficit in sexual behavior in adult rats neonatally exposed to citalopram is a consequence of $5-\mathrm{HT}_{1}$ receptor stimulation during development. Brain Research. 2006b;3(125): 171-5.

[56] Rayen I, Steinbusch H, Charlier TD, Pawluski JL. Developmental fluoxetine exposure and prenatal stress alter sexual differentiation of the brain reproductive behaviour in male rat offspring. Psychoneuroendocrinology. 2013;38:1618-29. 
[57] Khatri N, Simpson KL, Lin RC, Paul IA. Lasting neurobehavioural abnormalities in rats after neonatal activation of 5-HT 1A \& 1B receptors: Possible mechanism for 5-HT dysfunction in ASD. Psychopharmacology. 2013;231: 1191-200.

[58] Vieira ML, Hamada RY, Gonzaga NI, Bacchi AD, Barbieri M, Moreira EG, Mesquita SF, Gerardin DC. Could maternal exposure to the antidepressant fluoxetine and St John's Wort induce long-term reproductive effects on male rats? Reproductive Toxicology. 2013;35:102-7.

[59] Engel M, Smidt MP, van Hooft JA. The serotonin 5-HT3 receptor: A novel neurodevelopmental target. Front Cell Neurosci. 2013;27:7-76.

[60] Kinast K, Peeters D, Kolk SM, Schubert D, Homberg JR. Genetic and pharmacological manipulations of the serotonergic system in early life: Neurodevelopmental underpinnings of autism-related behavior. Front Cell Neurosci. 2013;7:72.

[61] Stroup DF, Berlin JA, Morton SC, Olkin I, Williamson GD, Rennie D, Moher D, Becker BJ, Sipe TA, Thacker SB. Meta-analysis of observational studies in epidemiology: A proposal for reporting. Meta-analysis Of Observational Studies in Epidemiology (MOOSE) group. JAMA. 2000;283:2008-12.

[62] Review Manager (RevMan) [Computer program]. Version 5.3. Copenhagen: The Nordic Cochrane Centre, The Cochrane Collaboration, 2014 (http://tech.cochrane.org/revman/download).

[63] Nulman I, Rovert J, Stewart DE, Wolpin J, Gardner HA, Theis J, Kulin N, Koren G. Neurodevelopment of children exposed in utero to antidepressant drugs. New England Journal of Medicine. 1997;336:258-62.

[64] Nulman I, Rovet J, Stewart DE, Wolpin J, Pace-Asciak P, Schuhaiber S, Koren G. Child development following exposure to tricyclic antidepressants or fluoxetine throughout fetal life: A prospective, controlled study. Am J Psych. 2002;159:1889-95.

[65] Nulman I, Koren G, Rovet J, Barrera M, Pulver A, Streiner D, Feldman B. Neurodevelopment of children following prenatal exposure to venlafaxine, SSRIs or untreated maternal depression. Am J Psych. 2012;169:1165-74.

[66] Suri R, Hellemann G, Stowe ZN, Cohen LS, Aquino A, Altschuler LL. A prospective, naturalistic blinded study of early neurobehavioural outcomes for infants following prenatal antidepressant exposure. J Clinical Psych. 2011;72: 1002-7.

[67] Casper RC, Fleisher BE, Lee-Ancajas JC, Gilles A, Gaylor E, Debattista A, Hoyme, HE. Follow-up of children of depressed mothers exposed or not exposed to antidepressant drugs during pregnancy. J Pediatr. 2003;142:402-8.

[68] Galbally M, Lewis AJ, Buist A. (2011) Developmental outcomes in children exposed to antidepressants in pregnancy. Aus \& NZ J of Psych. 2011;45:393-9.

[69] Clements CC, Castro VM, Blumenthal SR, Rosenfield HR, Murphy SN, Fava M, Erb JL, Churchill SE, Kaimal AJ, Doyle AE, Robinson EB, Smoller JW, Kohane IS, Perlis RH. Prenatal antidepressant exposure is associated with risk for ADHD but not ASD in a large health system. Molecular Psychiatry. 2014:1-8.

[70] Croen LA, Grether JK, Yoshida CK, Odouli R, Hendrick V. Antidepressant use during pregnancy and childhood ASDs. Arch Gen Psychiatry. 2011;68:1104-12.

[71] de Vries, NKS, van der Veere CN, Reijneveld SA, Bos AF. Early neurological outcome of young infants exposed to SSRIs during pregnancy: Results from the observational SMOK study. PLoS ONE. 2013;8(5):e64654.

[72] El Marroun H, White TJH, van der Knaap NJF, Hombery JR, Fernandez G, Schoemaker NK. Jaddoe VW, Hofman A, Verhulst FC, Hudziak JJ, Stricker BH, Tiemeier H. Prenatal exposure to selective serotonin reuptake inhibitors and social responsiveness symptoms of autism: Population-based study of young children. British J Psychiatry. 2014;205:95-102.

[73] Figueroa R. Use of antidepressants during pregnancy and risk of attention-deficit/hyperactivity disorder in the offsprind. J Dev Behav Pediatr. 2010;31:641-8.

[74] Gidaya NB, Lee BK, Burstyn I, Yudell MY, Mortensen EL, Newschaffer CJ. In utero exposure to SSRIs and risk for ASD. J Autism Dev Disord. 2014;44(10):2558-67. doi:10.1007/s10803-014-2128-4

[75] Hanley GE, Brain U, Oberlander TF. Infant developmental outcomes following prenatal exposure to antidepressants and maternal depressed mood and positive affect. Early Human Development. 2013;89:519-24.

[76] Harrington RA, Lee LC, Crum RM, Zimmerman AW, Hertz-Picciotto I. Prenatal SSRI use and offspring with ASD or developmental delay (DD). Pediatrics. 2014;133:1241-8.

[77] Hviid A, Melbye M, Pasternak B. Use of SSRIs during pregnancy \& risk of autism. New England J of Med. 2013;369:2406-15.

[78] Knickmeyer RC, Meltzer-Brody S, Woolson S, Hamer RM, Smith JK, Lury K, Gilmore JH. Rate of chiari I malformation in children of mothers with depression with and without prenatal SSRI exposure. Neuropsychopharmacology. 2014;39(11):2611-21.

[79] Langesen K, Olsen M, Andersen A, Froslev T, Sorensen H. In utero exposure to antidepressant drugs and risk of attention deficit hyperactivity disorder: A nationwide Danish cohort study. BMJ Open. 2013;3:e003507. doi:10.1136/bmjopen-2013-003507 
[80] Pedersen LH, Henriksen TB, Olsen J. Fetal exposure to antidepressant \& normal milestone development at 6 and 19 months of age. Pediatrics. 2010;125(3):e600-8. doi:10.1542/peds.2008-3655 [published online first Feb 2010].

[81] Rai D, Lee BK, Dalman C, Golding J, Lewis G, Magnusson CM. Parental depression, maternal antidepressant use during pregnancy and risk of autism spectrum disorders: Population based case-control study. BMJ. 2013;346:f2059. doi:10.1136/bmj.f2059

[82] Sorensen MJ, Gronborg TK, Christensen J, Parner ET, Vestergaard M, Schendel D, Pedersen LH. Antidepressant exposure in pregnancy \& risk of ASDs. Clin Epid. 2013;5:449-59.

[83] Brookwell L, Hogan C, Mangin D, Healy D. Ninety three cases of alcoholism triggered by serotonin reuptake inhibitor intake. Int J Risk \& Safety in Med. 2014;26:99-107.

[84] Xu Y, Sari Y, Zhou F. Selective serotonin reuptake inhibitor disrupts organization of thalamo-cortical somatosensory barrels during development. Developmental Brain Research. 2004;150:151-61.

[85] Borue X, Chen J, Condron BG. Developmental Effects of SSRI's-Lessons learned from Animal Studies. Int J Dev Neuroscience. 2007;25:341-7.

[86] Lee LJ. Neonatal fluoxetine exposure affects the neuronal structure in the somatosensory cortex and somatosensoryrelated behaviors in adolescent rats. Neurotox Res. 2009;15:212-23.

[87] Ansorge MS, Zhou M, Lira A, Hen R, Gingrich J. Early-life blockade of the 5- HT transporter alters emotional behavior in adult mice. Science. 2004;306:879-88.

[88] Aragon MA, Ayala ME, Marin M, Aviles A, Damian-Matsumura P, Dominguez R. Serotoninergic system blockage in the prepubertal rat inhibits spermatogenesis development. Reproduction. 2005;129:717-27.

[89] Price J, Cole V, Goodwin, GM. Emotional side-effects of selective serotonin reuptake inhibitors: Qualitative study. Br J Psych. 2009;195:211-7.

[90] Tranter R, Bell D, Gutting P, Harmer C, Healy D, Anderson I. The effect of serotonergic and noradrenergic antidepressants on emotional processing in clinically depressed patients. J Aff Dis. 2009;118:87-93.

[91] Schultz ST, Klonoff-Cohen HS, Wingard DL, Akshoomoff NA, Macera CA, Ji M. Acetaminophen (paracetamol) use, measles-mumps-rubella vaccination, and autistic disorder: The results of a parent survey. Autism. 2008;12:293-307.

[92] Gould GG, Seillier A, Weiss G, Giuffrida A, Burke TF, Hensler JG, Rock C, Tristan A, McMahon LR, Salazar A, O'Connor JC, Satsangi N, Satsangi RK, Gu TT, Treat K, Smolik C, Schultz ST. Acetaminophen differentially enhances social behavior and cortical cannabinoid levels in inbred mice. Progress in Neuro-Psychopharmacology \& Biological Psychiatry. 2012;38:260-9.

[93] Durso G, Luttrell A, Way B. Over-the-counter relief from pains and pleasures alike acetaminophen blunts evaluation sensitivity to both negative and positive stimuli. Psychol Sci. 2015;26:750-8.

[94] Gentiles S. Prenatal antidepressant exposure and the risk of autism spectrum disorderd in children. Are we looking at the fall of Gods? J of Aff Dis. 2015;182:132-7.

[95] Man K, Tong H, Wing L, Chan E, Simonoff E, Wong I. Exposure to selective serotonin reuptake inhibitors during pregnancy and risk of autism spectrum disorder in children: A systematic review and meta-analysis of observational studies. Neuroscience and Biobeh Rev. 2015;49;82-9.

[96] Green MD, Bendectin and Birth Defects. The Challenges of Mass Toxic Substances Litigation. U Pennsylvania Press, Phila Pa; 1996.

[97] Heinonen OP, Slone D, Shapiro S. Birth defects and drugs in pregnancy. Publishing Sciences Group. Littleton, Massachusetts; 1977.

[98] Smithells RW, Sheppard S. Teratogenicity testing in humans: A method demonstrating safety of Bendectin. Teratology. 1978;17:31-5.

[99] Fleming DM, Knox JD, Crombie DL. Debendox in early pregnancy and fetal malformation. Br Med J (Clin Res Ed). 1981;283:99-101.

[100] Shiono PH, Klebanoff MA. Bendectin and human congenital malformations. Teratology. 1989;40:151-5.

[101] Milkovich L, Van den Berg BJ. An evaluation of the teratogenicity of certain antinauseant drugs. Am J Obstet Gynecol. 1976;125:244-8.

[102] Rothman K, Fyler D, Goldblatt A, Kreidberg M. Exogenous hormones and other drug exposures of children with congenital heart disease. Am J Epidemiology. 1979;109:433-40.

[103] Jick H, Holmes LB, Hunter JR, Madsen S, Stergachis A. First trimester drug use and congenital disorders. JAMA.1981;246:343-6.

[104] Mitchell AA, Rosenberg L, Shapiro S, Slone D. Birth defects related to Bendectin use in pregnancy. I. Oral clefts and cardiac defects. JAMA. 1981;245:2311-4.

[105] Eskenazi B, Bracken MB. Bendectin (Debendox) as a risk factor for pyloric stenosis. Am J Obstet Gynecol. 1982;144:919-24.

[106] Morelock S, Hingson R, Kayne H, Dooling E, Zuckerman B, Day N, Alpert JJ, Flowerdew G. Bendectin and fetal development: A study of Boston City Hospital. Am J Obstet Gynecol. 1982;142:209-13. 
[107] Aselton, PJ, Jick H. Additional follow up of congenital limb disorders in relation to Bendectin use. JAMA. 1983;250: 33-4.

[108] Michaelis J, Michaelis H, Gluck E, Roller S. Prospective study of suspected associations between certain drugs administered during early pregnancy and congenital malformation. Teratology. 1983;27:57-64.

[109] Mitchell AA, Schwingl PJ, Rosenberg L, Louik C, Shapiro S. Birth defects in relation to Bendectin use in pregnancy. II. Pyloric stenosis. Am J Obstet Gynecol. 1983;147:737-42.

[110] Golding J, Vivian S, Baldwin JA. Maternal anti-nauseants and clefts of lip and palate. Human Toxicology. 1983;2:63-73.

[111] Aselton P, Jick H, Chentow SJ, Perera D, Hunter J, Rothman K. Pyloric stenosis and maternal Bendectin exposure. Am J Epidemiol. 1984;120:251-6.

[112] Zierler S, Rothman K. Congenital heart disease in relation to maternal use of Bendectin and other drugs in the early pregnancy. NEJM. 1985;313:347-53.

[113] Boneva R, Moore C, Botto L, Wong LY, Erickson J. Nausea during pregnancy and congenital heart defects: A population-based case-control study. Am J Epidemiol. 1999;149:717-25.

[114] Persaud N, Healy D. Epidemiology in forensic pharmacovigilance. Int J Risk \& Safety in Med. 2012;24:31-5.

[115] Gilboa SM, Strickland MJ, Olshan AF, Werler MM, Correa A. Use of antihistamine medications during early pregnancy and isolated major malformations. Birth Defects Research (Part A). 2009;85:37-150.

[116] Reis M, Kallen B. Delivery outcome after maternal use of antidepressant drugs in pregnancy. Psychol Med. 2010;40:1723-33.

[117] Charney D., Heath L, Zikos E, Palacios-Boix J, Gill K. Poorer drinking outcomes with citalopram treatment for alcohol dependence: A randomized, double-blind placebo-controlled trial. Alcohol Clin Exp Res. 2015. doi:10.1111/acer.12802

[118] Food and Drug Administration: Drug Bulletin. Washington DC, September; 1979;22-3.

[119] American Medical Association. Drug interactions and adverse drug reactions in AMA Drug Evaluation Bennett DR (ed). Chicago Il, American Medical Association; 1983;31-111.

[120] Wisner K, Perel J. Psychopharmacologic agents and electroconvulsive therapy during pregnancy. In: Cohen RL. Psychiatric Consultation in Childbirth Settings. New York, Plenum Press; 1988;165-206.

[121] Cohen LS, Heller VL, Rosenbaum JF. Treatment guidelines for psychotropic drug use in pregnancy. Psychosomatics. 1989;30:25-33.

[122] Stewart DE, Robinson GE. Psychotropic drugs and electroconvulsive therapy during pregnancy and lactation. In: Stewart DE, Stotland N, eds. Psychological Aspects of Women's Health Care. American Psychiatric Press Washington DC; 1993;71-96.

[123] Miller LJ. Psychiatric Disorders during Pregnancy. In: Stewart DE, Stotland N, eds. Psychological Aspects of Women's Health Care. American Psychiatric Press Washington DC; 1993;55-70.

[124] Brockington IF. Motherhood and Mental Illness. Oxford University Press, Oxford; 1996.

[125] Wisner KL, Sit DK, Hanusa BH, Moses-Kolko EL, Bogen DL, Hunker DF, Perel JM, Jones-Ivy S, Bodnar LM, Singer LT. Major depression and antidepressant treatment: Impact on pregnancy and neonatal outcomes. Am J Psychiatry. 2009;166:557-66.

[126] Robinson GE. Controversies about the use of antidepressants in pregnancy. J Nerv Ment Dis. 2015;203:159-63.

[127] Cohen LS, Altshuler LL, Harlow BL, Nonacs R, Newport DJ, Viguera AC, Suri R, Burt VK, Hendrick V, Reminick AM, Loughead, A, Vitonis AF, Stowe ZN. Relapse of major depression during pregnancy in women who maintain or discontinue antidepressant treatment. JAMA. 2006;295:499-507.

[128] Yonkers KA, Wisner KL, Stewart DE, Oberlander TF, Dell DL, Stotland N, Ramin S, Chaudron L, Lockwood C. The management of depression during pregnancy: A report from the American Psychiatric Association and the American College of Obstetricians and Gynecologists. General Hospital Psychiatry. 2009;31:403-13.

[129] Healy D. Serotonin and depression. BMJ. 2015;350:h177.

[130] Atigari OV, Kelly Q, Jabeen Q, Healy, D. New onset alcohol dependence linked to treatment with selective serotonin reuptake inhibitors. Int J Risk Saf Med. 2013;25:105-9.

[131] Wichman CL, Moore KM, Lang TR, St Sauver JL, Heise RH, Watson WJ. Congenital heart disease associated with selective serotonin reuptake inhibitor use during pregnancy. Mayo Clinic Proceedings. 2009;84:23-7.

[132] Healy D, Mangin D. Does my Bias Look Big in This? In: Baylis F, Ballantyne A (eds), Clinical Trials Involving Pregnant Women. Springer; 2016.

[133] Rothman KJ, Lanes S, Robins J. Casual inference. Epidemiology. 1993;4:555-6. 